\title{
ANALISIS FAKTOR-FAKTOR YANG MEMPENGARUHI DISIPLIN BELAJAR SISWA KELAS X, XI, DAN XII DI SMA BHAKTI YASA SINGARAJA TAHUN PELAJARAN 2016/2017.
}

\author{
Oleh \\ Siska Yuliyantika \\ Jurusan Pendidikan Ekonomi, Fakultas Ekonomi \\ Universitas Pendidikan Ganesha Singaraja, \\ Indonesia
}

\section{e-mail: siska.yuliyantika@yahoo.com}

\begin{abstract}
ABSTRAK
Penelitian ini bertujuan untuk mengetahui (1) faktor-faktor yang mempengaruhi disiplin belajar siswa kelas X, XI, dan XII di SMA Bhakti Yasa Singaraja tahun ajaran 2016/2017 dan (2) faktor yang paling dominan mempengaruhi disiplin belajar siswa kelas X, XI, dan XII di SMA Bhakti Yasa Singaraja tahun ajaran 2016/2017. Jenis penelitian ini merupakan penelitian factorial. Hasil penelitian menunjukkan, (1) terdapat lima faktor yang mempengaruhi disiplin belajar siswa kelas X, XI, dan XII di SMA Bhakti Yasa Singaraja tahun ajaran 2016/2017, yaitu keadaan fisik, keadaan psikis, kebiasaan keluarga, penerapan tata tertib sekolah, dan kondisi lingkungan masyarakat. Besarnya variance explained faktor secara berturut-turut, yaitu keadaan fisik sebesar $12,662 \%$, keadaan psikis sebesar $23,782 \%$, kebiasaan keluarga sebesar $16,540 \%$, penerapan tata tertib sekolah sebesar $38,498 \%$, dan kondisi lingkungan masyarakat sebesar $8,558 \%$. (2) faktor yang paling dominan mempengaruhi disiplin belajar siswa kelas X, XI, dan XII di SMA Bhakti Yasa Singaraja tahun ajaran 2016/2017, yaitu penerapan tata tertib sekolah dengan memiliki variance explained sebesar $38,498 \%$, artinya total nilai variance explained dari penerapan tata tertib sekolah mampu menjelaskan disiplin belajar siswa kelas X, XI, dan XII di SMA Bhakti Yasa Singaraja tahun ajaran 2016/2017.
\end{abstract}

Kata kunci: belajar, disiplin, siswa

\section{ABSTRACT}

This study aimed to know the (1) factors affect dicipline student learning class $\mathrm{X}, \mathrm{XI}$, and XII in high school Bhakti Yasa Singaraja academic year 2016/2017 and ( 2 ) dominant factors affect dicipline student learning class X, XI, and XII in high school Bhakti Yasa Singaraja academic year 2016 / 2017. Data was gathered using a questionnaire and analyzed with a factor analysis through spss 16.0 for windows. The results of study show ( 1 ) there are 5 factors that affect dicipline student learning class $X$, XI, and XII in high school Bhakti Yasa Singaraja academic year $2016 / 2017$, namely the physical condition, the state of psychic, habits family, the application of good governance school, and the condition of community. Amount of variance explained each factors are physical of $12,662 \%$, psychic of $23,782 \%$, habits family of $16,540 \%$, the application of good governance of $38,498 \%$ school, and environmental conditions society of $8,558 \%$. ( 2 ) dominant factors affect dicipline student learning class X, XI, and XII in high school Bhakti Yasa Singaraja academic year 2016 / 2017, is the application of good governance school by having variance explained of $38,498 \% \%$, it means the total value of variance explained from the application of good governance able to explain the discipline school student learning class X, XI, and XII in high school Bhakti Yasa Singaraja academic year 2016 / 2017.

Keywords : learning, discipline, student 


\section{PENDAHULUAN}

Setiap kegiatan sangat diperlukan kedisiplinan karena kedisiplinan adalah kunci berhasil atau gagalnya suatu kegiatan. Disiplin merupakan suatu bentuk kesadaran diri untuk mengendalikan dirinya. Dalam kaitannya dengan belajar, disiplin belajar berfungsi sebagai pengendali diri yang berada pada diri seseorang sehingga belajar akan penuh kesadaran dan tanpa paksaan, hal ini sejalan dengan pendapat Fathurrohman (2010:14) yang menyatakan "disiplin merupakan kesadaran untuk melakukan sesuatu pekerjaan dengan tertib dan teratur sesuai dengan peraturan-peraturan yang berlaku dengan penuh tanggung jawab tanpa paksaan dari siapapun". Dalam disiplin belajar memerlukan prinsip agar pembelajaran berhasil maka semua pihak harus memperhatikan dan memahami prinsip-prinsip belajar. Khususnya bagi siswa sebelum melaksanakan proses pembelajaran agar pembelajaran nantinya dapat berhasil maka siswa harus siap belajar, memberikan perhatian terhadap materi yang dipelajari, memiliki motivasi untuk belajar agar siswa dapat aktif pada saat proses pembelajaran berlangsung, siswa diberikan materi pelajaran yang menantang dengan metode pembelajaran yang tepat sehingga siswa termotivasi untuk belajar secara mandiri.

Menurut Zainal Aqib (2002), disiplin adalah satu aspek kehidupan yang mesti diwujudkan dalam masyarakat. Oleh karena itu siswa hendaklah mendapat perhatian dari semua pihak yang ada di sekolah maupun di luar sekolah. Perhatian yang diberikan kepada siswa diharapkan menumbuhkan sikap disiplin siswa utamanya dalam belajar karena siswa merasa diawasi.

Menurut Gunarsa (2012), disiplin belajar merupakan ketaatan dan kepatuhan terhadap peraturan tertulis maupun yang tidak tertulis dalam proses perubahan tingkah laku yang menetap akibat dari praktik yang berupa pengalaman mengamati, membaca, menirukan, mencoba sesuatu, mendengarkan, serta mengikuti arahan. Disiplin belajar bagi siswa diartikan lebih khusus sebagai tindakan yang menunjukkan ketaatan dan kepatuhan terhadap aturan, baik tertulis maupun tidak tertulis dalam kegiatan mencari pengetahuan dan kecakapan baru.

Menurut Unaradjan (2003), bertindak disiplin akan membantu siswa dalam penyesuaian diri dan penyesuaian sosial. Siswa yang disiplin akan mudah melakukan penyesuaian diri terhadap lingkungan sekitarnya dan disegani di lingkungannya. Sikap disiplin sangat penting bagi siswa karena disiplin bertujuan untuk menciptakan keteraturan hidup dalam bermasyarakat, siswa yang berdisiplin diri memiliki keteraturan diri berdasarkan nilai agama, nilai budaya, aturan-aturan pergaulan, pandangan hidup, dan sikap hidup yang bermakna bagi dirinya sendiri, masyarakat, bangsa, dan negara. Siswa yang memiliki sikap disiplin akan mudah untuk diatur baik dalam kehidupan bermasyarakat maupun lingkungan sekolah sehingga tujuan pembelajaran disekolah dapat tercapai dengan baik. Maka dari itu sikap disiplin belajar harus ditanamkan pada setiap siswa karena disiplin belajar bertujuan untuk menciptakan keteraturan dalam kegiatan belajar dan bermasyarakat. Menurut Tu'u (2004) beberapa fungsi disiplin yaitu;

1) Menata kehidupan bersama

Sikap disiplin diperlukan dalam kehidupan bermasyarakat. Disiplin akan berpengaruh terhadap tata kehidupan bermasyarakat setiap individu. Sikap disiplin masing-masing anggota masyarakat akan membuat hubungan yang baik antara anggota masyarakat satu dengan anggota masyarakat yang lain. Hal ini disebabkan karena masing-masing anggota masyarakat bertindak dengan penuh rasa tanggung jawab, sehingga setiap anggota dapat menata kehidupan bermasyarakat dengan baik.

2) Membangun kepribadian

Lingkungan yang memiliki sikap disiplin yang baik sangat berpengaruh terhadap kepribadian seseorang. Terutama bagi siswa yang sedang membentuk kepribadiannya, maka dari itu kondisi lingkungan sekolah dan lingkungan keluarga memiliki pengaruh yang kuat terhadap pembentukan kepribadian siswa. Lingkungan sekolah yang tertib, teratur, dan disiplin memiliki peran penting dalam membangun kepribadian yang baik. Selain 
lingkungan sekolah, untuk membangun kepribadian yang baik diperlukan lingkungan keluarga yang memiliki sikap disiplin yang baik, sehingga siswa setiap harinya akan terlatih untuk bertindak disiplin dan penuh tanggung jawab.

3) Melatih kepribadian

Disiplin berfungsi untuk melatih kepribadian siswa. Siswa harus berada pada lingkungan yang baik untuk berlatih membiasakan diri bersikap disiplin. Lingkungan yang dimaksud ialah lingkungan dimana terdapat individuindividu yang memiliki sikap disiplin dan dijadikan tauladan oleh siswa. Pada lingkungan sekolah siswa biasanya meniru sikap dari guru yang siswa segani, maka dari itu guru harus memberikan contoh sikap disiplin dan bertanggung jawab kepada siswa, sehingga siswa akan melatih kepribadiannya dengan meniru sikap disiplin dari guru tersebut. Dalam pembelajaran guru juga harus melatih kepribadian siswa, agar siswa melatih kepribadian mereka dengan membiasakan diri mengikuti dan mentaati peraturan yang ada di lingkungan sekolah maupun di rumah. Siswa yang sudah terbiasa mentaati peraturan yang ada dilingkungannya, maka siswa tersebut telah melatih kepribadiannya untuk menjadi siswa yang disiplin dan bertanggung jawab atas tugas-tugas yang diberikan.

4) Pemaksaan

Disiplin dapat berfungsi sebagai pemaksaan kepada seseorang untuk mengikuti peraturan-peraturan yang berlaku di lingkungan itu. Pemaksaan ini berdampak positif, karena dengan dipaksanya seseorang untuk berperilaku disiplin, akan membuat orang tersebut terlatih mengikuti aturan-aturan yang ada di lingkungannya. Bentuk pemaksaan yang ada disekolah yaitu siswa yang tidak mengikuti aturan yang ada disekolah dan bersikap tidak disiplin akan diberikan hukuman atau sanksi sesuai dengan pelanggaran yang dilakukan.

5) Hukuman

Hukuman ialah sanksi yang diberikan kepada siswa saat melanggar atau tidak mentaati aturan-aturan yang ada di lingkungannya. Dengan adanya sanksi tersebut siswa akan merasa takut untuk melanggar aturan yang ada, maka dari itu bentuk dan jenis hukuman disesuaikan dengan jenis pelanggaran yang dilakukan oleh siswa. Hukuman yang diberikan kepada siswa yang tidak disiplin bertujuan untuk memberikan dorongan kepada siswa agar mentaati aturan-aturan yang ada di lingkungannya.

6) Menciptakan lingkungan kondusif

Lingkungan pendidikan yang kondusif adalah lingkungan yang nyaman, tenang, dan tidak ada gangguan dalam melaksanakan proses pembelajaran, sehingga siswa dan guru dapat melaksanakan proses belajar mengajar dengan baik. Untuk mewujudkan terciptanya lingkungan sekolah yang kondusif maka pihak sekolah membuat peraturan sekolah yang diterapkan bagi semua pihak sekolah. Peraturan sekolah yang diimplementasikan dengan baik dapat memberi pengaruh bagi terciptanya sekolah sebagai lingkungan pendidikan yang kondusif bagi kegiatan pembelajaran. Karena lingkungan pendidikan yang kondusif akan membuat siswa nyaman dalam mengikuti proses pembelajaran dan memudahkan tercapainya tujuan pembelajaran.

Dalam kegiatan belajar mengajar disiplin belajar sangat penting, karena dengan adanya disiplin siswa dapat belajar dengan baik. Siswa yang terbiasa dalam disiplin belajar akan mempergunakan waktu sebaik-baiknya di rumah maupun di sekolah sehingga akan menunjukkan kesiapannya dalam proses pembelajaran di sekolah, sedangkan siswa yang tidak disiplin belajar mereka kurang menunjukkan kesiapannya dalam belajar dan menunjukkan perilaku yang tidak baik dalam proses pembelajaran seperti tidak mengerjakan PR, membolos, tidak memperhatikan penjelasan guru, melanggar tata tertib sekolah yang lainnya. Unaradjan (2003) menyebutkan bahwa disiplin dipengaruhi oleh dua faktor yaitu faktor internal dan eksternal. (1) Faktor internal merupakan faktor-faktor yang berasal dari siswa sendiri dan dapat mempengaruhi disiplin belajarnya. Dalam hal ini faktor internal dibagi menjadi dua yaitu keadaan fisik dan psikis merupakan aspek yang mempengaruhi pembentukan disiplin diri. (2) Faktor eksternal yaitu faktor- 
faktor yang berasal dari lingkungan luar dan dapat mempengaruhi disiplin belajar siswa. Faktor eksternal tersebut meliputi kebiasaan keluarga, penerapan tata tertib sekolah, dan kondisi masyarakat.

Dalam penyelenggaraan kegiatan pembelajaran SMA Bakti Yasa Singaraja telah menyusun berbagai aturan-aturan tata tertib akademik maupun non akademik, semua aturan berupa tata tertib ini harus ditaati oleh semua warga sekolah yaitu guru, siswa, maupun tenaga kependidikan. Tata tertib yang ada di SMA Bakti Yasa antara lain siswa berpakaian rapi, tidak boleh terlambat datang kesekolah, siswa tidak boleh merokok dan membawa handphone ke sekolah, siswa harus menjaga komunikasi yang baik antara siswa dengan siswa dan siswa dengan guru, siswa yang tidak hadir harus mengirimkan surat keterangan sakit atau ijin dari orang tua, dan masih banyak lagi tata tertib yang ada di SMA Bakti Yasa. Dengan adanya tata tertib yang telah dibuat oleh pihak sekolah diharapkan dapat membentuk disiplin semua warga sekolah yaitu guru, siswa, maupun tenaga kependidikan.

Namun berdasarkan hasil dari observasi awal yang dilakukan peneliti di SMA Bakti Yasa Singaraja khususnya kelas $X$ dan $\mathrm{XI}$ menunjukkan bahwa disiplin siswa secara umum masih relatif rendah. Hal ini terlihat dari keseharian siswa di sekolah, sebagian besar siswa terlihat belum mematuhi tata tertib yang telah dibuat antara lain banyak siswa yang tidak hadir atau terlambat masuk kelas, tingkat absensi siswa yang tinggi, cara berpakaian yang tidak rapi, maupun perilaku siswa yang tidak memperhatikan guru saat memberikan materi dikelas, dan tidak semua siswa mengerjakan tugas yang diberikan. Melihat rendahnya tingkat disiplin siswa, maka penulis tertarik untuk meneliti mengenai faktor-faktor apa saja yang mempengaruhi disiplin belajar siswa kelas $\mathrm{X}$ dan $\mathrm{XI}$ di SMA Bakti Yasa Singaraja.

Dari latar belakang yang telah ditentukan, maka dapat dirumuskan masalah sebagai berikut, (1) faktor-faktor apa saja yang mempengaruhi disiplin belajar siswa kelas X dan XI di SMA Bakti
Yasa Singaraja tahun pelajaran 2015/2016?, (2) faktor mana yang paling dominan mempengaruhi disiplin belajar siswa kelas X dan XI di SMA Bakti Yasa Singaraja tahun pelajaran 2015/2016?.

Meninjau dari permasalahan yang ada maka tujuan penelitian ini adalah, (a) untuk mengetahui faktor-faktor yang mempengaruhi disiplin belajar siswa kelas $X$ dan XI di SMA Bakti Yasa Singaraja tahun pelajaran 2015/2016, (b) untuk mengetahui faktor dominan yang mempengaruhi disiplin belajar siswa kelas $X$ dan XI di SMA Bakti Yasa Singaraja tahun pelajaran 2015/2016.

Manfaat dari penelitian ini yaitu, (1) manfaat praktis, (a) masukan bagi pihak sekolah untuk lebih meningkatkan kualitas hasil belajar siswanya dengan memperhatikan faktor-faktor yang mempengaruhi disiplin belajar siswa, (b) memberikan sumbangan bagi pihak guru dalam meningkatkan hasil belajar siswa dengan memperhatikan informasi tentang faktor-faktor yang mempengaruhi disiplin belajar, (c) memberikan masukan bagi siswa untuk meningkatkan prestasi belajar siswa dengan memperhatikan informasi tentang faktor-faktor yang mempengaruhi disiplin belajar siswa terutama tentang kondisi dalam diri siswa yang meliputi bakat, minat dan motivasi, serta lingkungan yang mempengaruhi hasil belajarnya. (2) Manfaat teoritis, hasil penelitian ini dapat digunakan sebagai masukan penelitian selanjutnya dengan menambah variabel lain yang berhubungan dengan usaha mencapai tujuan pendidikan.

\section{METODE}

Populasi pada penelitian ini adalah siswa kelas X, XI, dan XII di SMA Bhakti Yasa Singaraja tahun ajaran 2016/2017 dengan jumlah sebanyak 33 siswa. Adapun jumlah populasi dalam penelitian ini dapat dilihat pada tabel 1. 
Tabel 1. Jumlah Populasi Siswa SMA Bhakti Yasa Singaraja Tahun Ajaran 2016/2017

\begin{tabular}{cccc}
\hline No & Kelas & Jumlah \\
\hline & $\mathbf{1}$ & $\mathrm{X}$ & 9 Orang \\
& $\mathbf{2}$ & $\mathrm{XI}$ & 14 Orang \\
& & $\mathrm{XII}$ & 10 Orang \\
& \multirow{3}{*}{ Jumlah } & 33 Orang \\
\hline
\end{tabular}

Mengingat jumlah populasi yang sedikit, maka akan diambil seluruhnya untuk dijadikan sampel yaitu sebanyak 33 siswa.

Pengumpulan data dilakukan dengan metode dokumentasi dan kuesioner atau angket. Kuesioner dalam penelitian ini disebarkan kepada 33 responden yang merupakan seluruh siswa kelas $\mathrm{X}, \mathrm{XI}$, dan XII di SMA Bhakti Yasa Singaraja tahun ajaran 2016/2017. jenisnya, data yang digunakan dalam penelitian ini adalah data kualitatif. Data kualitatif dalam penelitian ini berupa data yang diperoleh dari responden (siswa) SMA Bakti Yasa mengenai disiplin belajar siswa kelas X dan XI di SMA Bakti Yasa Tahun Ajaran 2016/2017. Sumber data yang digunakan dalam penelitian ini yaitu, (1) data primer, diperoleh dari responden secara langsung melalui kuesioner yang diisi sendiri oleh responden yang dijadikan sampel penelitian, (2) data sekunder, diperoleh dari dokumendokumen atau data-data yang terdapat pada ruang tata usaha sekolah yang berupa data nama siswa kelas $\mathrm{X}, \mathrm{XI}$, dan XII di SMA Bhakti Yasa Singaraja tahun ajaran 2016/2017, dan absensi siswa yang berupa data kehadiran siswa di sekolah. Analisis data yang digunakan penelitian ini adalah analisis faktor. pengujian hipotesis dilakukan dengan menggunakan Statistical Program Social Scence (SPSS) 16.0 for Windows dengan menggunakan factor analysis.

\section{HASIL DAN PEMBAHASAN HASIL}

Data yang berhasil dikumpulkan dari kuesioner yang disebarkan dan setelah diolah dengan SPSS 16.0 for Windows menunjukkan faktor-faktor yang mempengaruhi disiplin belajar siswa kelas X, XI, dan XII di SMA Bhakti Yasa Singaraja tahun ajaran 2016/2017 dapat dijelaskan oleh persentase dari masing-masing faktor. Nilai total Variance Explained digunakan untuk mengetahui persentase dari lima faktor yang dianalisis. Hasil analisis faktor melalui SPSS menunjukkan persentase dari masing-masing faktor dapat dilihat pada Tabel 2 berikut.

Tabel 2. Total Variance Explained

\begin{tabular}{|c|c|c|c|c|c|c|c|c|c|}
\hline \multirow{3}{*}{$\begin{array}{l}\text { Co } \\
\text { mp } \\
\text { on } \\
\text { ent }\end{array}$} & \multirow{2}{*}{\multicolumn{3}{|c|}{ Initial Eigenvalues }} & \multirow{2}{*}{\multicolumn{3}{|c|}{$\begin{array}{l}\text { Extraction Sums of } \\
\text { Squared Loadings }\end{array}$}} & \multicolumn{3}{|c|}{ Rotation Sums of Squared } \\
\hline & & & & & & & & Loading & \\
\hline & Total & $\begin{array}{c}\% \text { of } \\
\text { Variance }\end{array}$ & $\begin{array}{c}\text { Cumulative } \\
\%\end{array}$ & Total & $\begin{array}{l}\text { \% of } \\
\text { Varianc } \\
\mathrm{e}\end{array}$ & $\begin{array}{l}\text { Cumulati } \\
\text { ve } \%\end{array}$ & Total & $\begin{array}{c}\% \text { of } \\
\text { Variance }\end{array}$ & $\begin{array}{c}\text { Cumulative } \\
\%\end{array}$ \\
\hline 1 & .631 & 12.662 & 91.442 & & & & & & \\
\hline 2 & 1.189 & 23.782 & 62.280 & 1.189 & 23.782 & 62.280 & 1.414 & 28.271 & 62.280 \\
\hline 3 & .827 & 16.540 & 78.820 & & & & & & \\
\hline 4 & 1.925 & 38.498 & 38.498 & 1.925 & 38.498 & 38.498 & 1.700 & 34.009 & 34.009 \\
\hline 5 & .428 & 8.558 & 100.000 & & & & & & \\
\hline
\end{tabular}


Berdasarkan tabel 2 dapat dilihat bahwa (1) faktor keadaan fisik memiliki eigenvalue sebesar 0,631 dengan nilai varian sebesar $12,662 \%$, (2) faktor keadaan psikis memiliki eigenvalue sebesar 1,189 dengan nilai varian sebesar $23,782 \%$, (3) faktor kebiasaan keluarga memiliki eigenvalue sebesar 0,827 dengan nilai varian sebesar $16,540 \%$, (4) faktor penerapan tata tertib sekolah memiliki eigenvalue sebesar 1,925 dengan nilai varian sebesar $38,498 \%$, dan (5) faktor kondisi lingkungan masyarakat memiliki eigenvalue sebesar 0,428 dengan nilai varian sebesar $8,558 \%$.

Untuk menjelaskan disiplin belajar siswa kelas X, XI, dan XII di SMA Bhakti
Yasa Singaraja tahun ajaran 2016/2017, dapat dilakukan dengan ekstraksi faktor. Ekstraksi faktor dapat dijelaskan oleh total persentase dari masing-masing faktor utama. Faktor-faktor utama tersebut adalah faktor psikis dan penerapan tata tertib sekolah yang memiliki nilai parameter eigenvalue $>1$. Untuk mengetahui distribusi dimensi-dimensi yang belum dirotasi kedalam faktor yang telah terbentuk maka dapat dilihat pada output SPSS 16.0 (Rotated Component Matrix). Faktor yang mampu menjelaskan disiplin belajar siswa kelas X, XI, dan XII di SMA Bhakti Yasa Singaraja tahun ajaran 2016/2017, dapat dilihat pada Tabel 3 berikut.

Tabel 3. Faktor yang menjelaskan disiplin belajar siswa kelas X. XI, dan XII di SMA Bhakti Yasa Singaraja tahun ajaran 2016/2017

\begin{tabular}{|c|c|}
\hline Eigenvalue & Varianced Explained (\%) \\
\hline Keadaan Fisik & 12.662 \\
\hline Keadaan Psikis & 23.782 \\
\hline Kebiasaan Keluarga & 16.540 \\
\hline $\begin{array}{l}\text { Penerapan Tata Tertib } \\
\text { Sekolah }\end{array}$ & 38.498 \\
\hline $\begin{array}{l}\text { Kondisi Lingkungan } \\
\text { Masyarakat }\end{array}$ & 8.558 \\
\hline $\begin{array}{l}\text { Berdasarkan dari Tabel } 3 \text { di atas, } \\
\text { dapat dijelaskan bahwa faktor yang } \\
\text { memiliki eigenvalue }>1 \text { adalah fakor } \\
\text { keadaan psikis dan penerapan tata tertib } \\
\text { sekolah, total nilai varianced explained dari } \\
\text { kedua faktor keseluruhan mampu } \\
\text { menjelaskan sebesar } 62,280 \% \text {. Dengan } \\
\text { demikian } 62,280 \% \text { dari seluruh variabel } \\
\text { yang ada, dapat dijelaskan oleh dua faktor } \\
\text { yang terbentuk. Keadaan psikis memiliki } \\
\text { varianced explained } 23,782 \% \text { artinya } \\
\text { bahwa faktor keadaan psikis mampu } \\
\text { mempengaruhi disiplin belajar siswa }\end{array}$ & $\begin{array}{l}\text { sebesar } 23,782 \% \text {. Penerapan tata tertib } \\
\text { sekolah memiliki variance explained } \\
38,498 \% \text { artinya bahwa penerapan tata } \\
\text { tertib sekolah mempengaruhi disiplin belajar } \\
\text { siswa sebesar } 38,498 \% \text {. } \\
\text { Menentukan nama faktor yang telah } \\
\text { terbentuk untuk masing-masing faktor } \\
\text { bersifat subjektif, kadangkala variabel yang } \\
\text { memiliki nilai faktor loading tertinggi } \\
\text { digunakan untuk memberi nama faktor. } \\
\text { Untuk melihat nilai faktor loading dapat } \\
\text { dilihat pada Tabel } 4 \text { berikut. }\end{array}$ \\
\hline
\end{tabular}


Tabel 4. Rotated Component Matrix

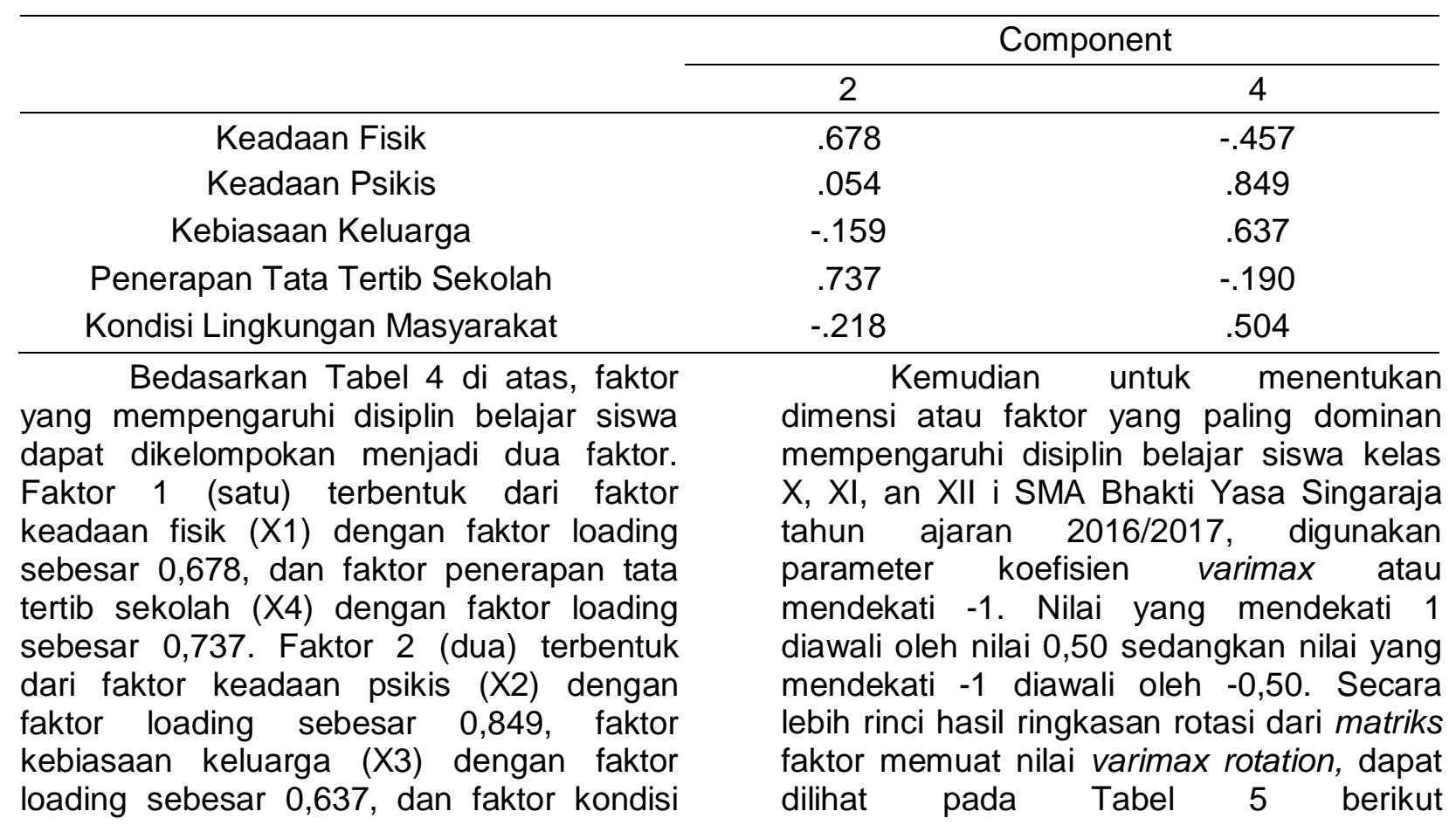
lingkungan masyarakat dengan faktor loading 0,504 .

Tabel 5. Matriks Rotasi Hasil Anallisis Faktor

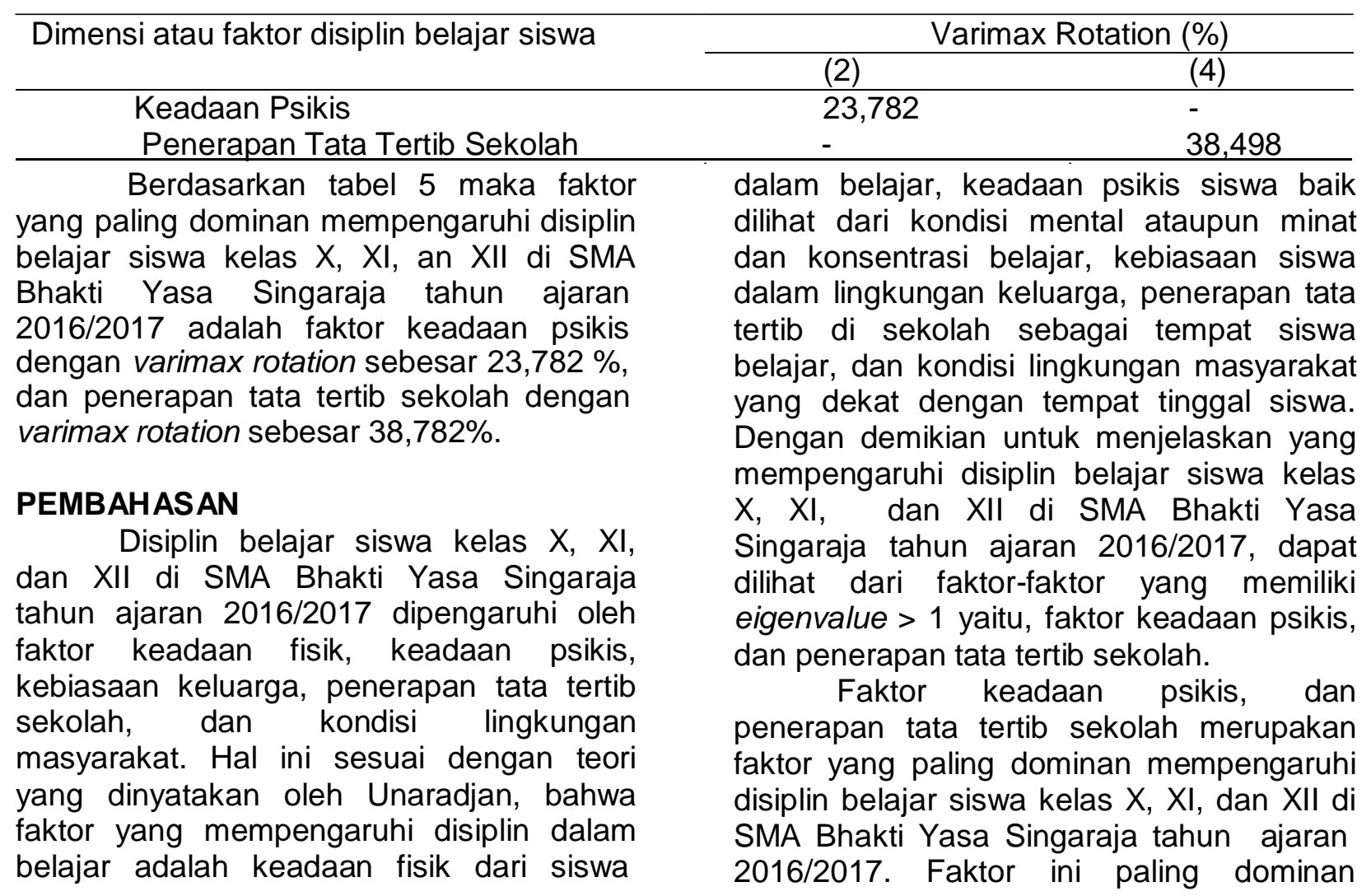


dibandingkan faktor-faktor yang lain disebabkan karena keadaan psikis adalah faktor yang terdapat dalam diri siswa dan tidak dapat terlihat, keadaan psikis ini berhubungan dengan psikologi dari siswa tersebut. Penghayatan norma keluarga dan masyarakat dapat dilakukan bagi individu yang sehat secara psikis atau mental. Terdapat beberapa sifat yang dapat menjadi penghalang pembentukan disiplin diri, yaitu perfeksionisme dan perasaan rendah diri. Perasaan perfeksionisme dan perasaan rendah diri siswa membuat siswa terdorong untuk melanggar peraturan di sekolah agar mendapat perhatian dari guru dan teman-teman di sekolahnya. Hasil penelitian ini sejalan dengan teori Unaradjan (2003), keadaan psikis meliputi minat siswa belajar, konsentrasi siswa dalam belajar, dan motivasi siswa untuk belajar. Ketiga indikator tersebut adalah hal penting dalam menentukan keberhasilan siswa dalam belajar dan disiplin belajar.

Penerapan tata tertib sekolah merupakan salah satu dari faktor eksternal yang mempengaruhi disiplin belajar siswa. Sekolah merupakan lingkungan kedua yang dekat dengan siswa. Sekolah merupakan tempat siswa untuk menuntut ilmu secara formal. Penanaman disiplin di sekolah bergantung dengan ada tidaknya sarana dan prasarana yang mendukung. Contoh pihak pendukung perkembangan disiplin anak yaitu guru. Guru yang dapat membina kedisiplinan anak secara umum harus memiliki aspek kualifikasi personal dan profesional. Selain itu, faktor sekolah yang mempengaruhi belajar ini mencakup metode mengajar, kurikulum, relasi guru dengan siswa, relasi siswa dengan siswa, disiplin sekolah, pelajaran dan waktu sekolah, standar pelajaran, keadaan gedung, metode belajar dan tugas rumah. Agar tujuan pembelajaran tercapai pihak sekolah menerapkan tata tertib sekolah yang harus dipatuhi oleh seluruh warga sekolah. Penerapan tata tertib sekolah yang baik akan memudahkan sekolah dalam membentuk karakter siswa, utamanya disiplin belajar. Hasil penelitian ini sejalan dengan teori Unaradjan (2003), penerapan tata tertib sekolah sangat berpengaruh terhadap tingkah laku siswa di sekolah, pihak guru yang menerapkan tata tertib secara tegas akan membentuk karakter siswa yang disiplin, begitu juga sebaliknya saat aturan di sekolah tidak di terapkan dengan tegas maka siswa akan menjadi tidak disiplin di sekolah.

\section{SIMPULAN DAN SARAN SIMPULAN}

Berdasarkan hasil analisis data dan pembahasan, maka dapat ditarik simpulan yaitu, (1) faktor-faktor yang mempengaruhi disiplin belajar siswa kelas X, XI, dan XII di SMA Bhakti Yasa Singaraja tahun ajaran 2016/2017 adalah, (a) keadaan fisik dengan nilai varian sebesar $12,662 \%$, (b) faktor keadaan psikis dengan nilai varian sebesar $23,782 \%$, (c) faktor kebiasaan keluarga dengan nilai varian $16,540 \%$, (d) faktor penerapan tata tertib sekolah dengan nilai varian 38,498\%, (e) dan faktor kondisi lingkungan masyarakat dengan nilai varian $8,558 \%$. (2) Faktor yang paling dominan mempengaruhi disiplin belajar siswa kelas X, XI, dan XII di SMA Bhakti Yasa Singaraja tahun ajaran 2016/2017 adalah penerapan tata tertib sekolah dengan nilai varimax rotation sebesar $38,498 \%$, dan faktor keadaan psikis dengan nilai varimax rotation $23,782 \%$.

\section{SARAN}

Berdasarkan pembahasan dan kesimpulan di atas, maka dapat diajukan beberapa saran yaitu, (1) bagi Sekolah, (a) diharapkan bagi pihak sekolah untuk menerapkan aturan-aturan sekolah secara tegas, dengan memberikan hukuman atau sanksi yang tegas kepada siswa yang melanggar tata tertib sekolah. Dengan sanksi yang tegas diharapkan tidak terjadi pelanggaran terhadap aturan disiplin sekolah, (b) selain untuk siswa, penerapan tata tertib sekolah secara tegas juga harus diberlakukan untuk seluruh warga sekolah seperti guru, dan tenaga kependidikan. Guru sebagai teladan siswa di sekolah juga harus mematuhi aturan sekolah seperti hadir tepat waktu, dan memakai pakaian yang rapi sesuai aturan yang berlaku. Bagi guru yang melanggar aturan sekolah juga harus diberikan sanksi atau hukuman yang disesuaikan dengan pelanggaran yang dilakukan, (c) hasil dari penelitian ini menyatakan bahwa keadaan psikis dan 
penerapan tata tertib sekolah menjadi faktor dominan yang mempengaruhi disiplin belajar siswa SMA Bhakti Yasa Singaraja, tanpa mengabaikan faktor yang lain hasil ini bisa dijadikan salah satu sumber informasi bagi pihak sekolah, utamanya bagi guru diharapkan bisa memberikan siswa motivasi yang menumbuhkan sikap disiplin siswa.

(2) Bagi siswa, (a) khususnya siswa kelas X, XI, dan XII yang dipersiapkan untuk mengikuti ujian nasional (UN), agar dapat memotivasi diri dalam mengikuti proses pembelajaran dan bersikap disiplin. Motivasi untuk belajar dalam diri siswa sangat diperlukan karena saat siswa termotivasi untuk belajar maka siswa akan berkonsentrasi penuh memperhatikan materi yang disampaikan oleh guru, (b) siswa diharapkan bisa mentaati tata tertib yang ada di sekolah untuk membentuk karakter diri yang disiplin dan bertanggung jawab. Siswa yang disiplin akan menyelesaikan segala tugas dari sekolah dengan baik dan tekun. Siswa yang mengerjakan tugas sekolah dengan tekun dan rajin mengikuti pelajaran di sekolah akan memudahkan guru dalam mencapai tujuan pembelajaran. Agar proses pembelajaran berlangsung dengan baik, diperlukan adanya penerapan tata tertib sekolah yang tegas, dan adanya sanksi atau hukuman bagi siswa yang melanggar tata tertib sekolah. (3) Bagi peneliti lain yang berminat untuk mendalami mengenai faktor-faktor yang mempengaruhi disiplin belajar siswa diharapkan melakukan penelitian lebih lanjut. Hal ini berguna untuk membandingkan faktor-faktor yang mempengaruhi disiplin belajar siswa yang terjadi di sekolah satu dengan yang lainnya.

\section{DAFTAR PUSTAKA}

Agoes

Dariyo. 2004. Psikologi Perkembangan Remaja. Bogor: Ghalia Indonesia.

Agus Wibowo. 2012. Pendidikan Karakter. Yogyakarta: Pustaka Pelajar.

Atifah, Nur. 2006. Hubungan Tingkat Kedisiplinan dengan Prestasi Belajar Sosiologi bagi Siswa Kelas XI IPS Madrasah Aliyah
Negeri Babakan Lebaksiu Tegal Tahun Pelajaran 2005/2006.

Aunurrahman. 2009. Belajar dan Pembelajaran. Bandung: Alfabeta.

Baharuddin dan Esa. 2008. Teori Belajar dan Pembelajaran. Jogjakarta: Ar-Ruzz Media.

Chaplin, J. P. 2004. Kamus Umum Psikologi (Penerjemah Kartini Kartono). Jakarta: PT Raja Grafindo Persada.

Darsono, Max. 2000. Belajar dan Pembelajaran. Semarang: IKIP Semarang Press.

Darsono. 2001. Belajar dan Pembelajaran. Semarang: IKIP Semarang Press.

Daryanto. 2015. Teori Belajar dan Proses Pembelajaran. Yogyakarta: Gava Media.

Dimyati dan Mudjiono, 2006. Belajar dan Pembelajaran. Jakarta: Rineka Cipta.

Dwi Siswoyo, dkk. 2008. Ilmu Pendidikan. Yogyakarta: UNY Press.

Fahturrohmah, Pupuh dan M Sobry Sutikno. 2010.Strategi Belajar Mengajar. Bandung: Refika.

Gunarsa . 2012. Psikologi untuk Membimbing. Jakarta: Libri.

Hamalik, Oemar. 2006. Perencanaan Pengajaran Berdasarkan

Pendekatan Sistem. Jakarta: Bumi Aksara.

Mengajar. Jakarta : Belajar
Aksara.

Khafid, Muhammad. dan Suroso. 2007. Pengaruh Disiplin Belajar dan Lingkungan Keluarga terhadap Hasil Belajar Ekonomi. Jurnal Pendidikan Ekonomi Vol 2 No. 2. Semarang.

Mardapi, Djemari. 2008. Teknik Penyusunan Instrumen Tes dan Nontes. Jogjakarta: Mitra Cendikia Press.

Muh. Farozin \& Kartika Nur Fathiyah. 2003. Pemahaman Tingkah Laku. Jakarta: PT Rineka Cipta.

Muhammad Fauzani, Ngalimun. 2015. Strategi dan Model 
Pembelajaran. Yogyakarta: Aswaja Pressindo. .2016. Strategi dan Model Pembelajaran. Yogyakarta: Aswaja Pressindo

Purwanto, Ngalim. 2008. Prinsip-Prinsip dan Teknik Evaluasi Pengajaran. Bandung: PT Remaja Rosdakarya.

Sardiman AM., 2007. Interaksi dan Motivasi Belajar Mengajar. Jakarta: PT RajaGrafindo Persada.

Sardiman AM., 2011. Interaksi dan Motivasi Belajar Mengajar. Jakarta: PT RajaGrafindo Persada. .2014. Interaksi dan Motivasi Belajar Mengajar. Jakarta: PT RajaGrafindo Persada.

Slameto. 2006. Belajar \& faktor-faktor yang Mempengaruhinya. Jakarta : Rineka Cipta.

2010. Belajar \& faktor-faktor yang Mempengaruhinya. Jakarta : Rineka Cipta.

Sagala, Syaiful. 2012. Konsep dan Makna Pembelajaran. Bandung : Alfabeta.

Sugiyono. 2010. Metode Penelitian Pendidikan (Pendekatan Kuantitatif, Kualitatif, dan R\&D). Bandung: ALFABETA.

Suharsimi, Arikunto. 2002. Dasar-Dasar Evaluasi Pendidikan. Jakarta : Bumi Aksara.
--.-2006. Prosedur Penelitian Suatu Pendekatan Praktik. Jakarta: RinekaCipta.

Supranto. 2004. Analisis Multivariat Arti dan Interpretasi. Jakarta: Rineka Cipta.

Tutik Rachmawati. 2011. Teori Belajar dan Proses Pembelajaran yang Mendidik. Yogyakarta: Gava Media.

Tutik Rachmawati. 2015. Teori Belajar dan Proses Pembelajaran yang Mendidik. Yogyakarta: Gava Media.

Tu'u, Tulus. 2004. Peran Disiplin pada Perilaku dan Prestasi Siswa. Jakarta: Grasindo.

Unaradjan Dolet. 2003. Manajemen Disiplin. Jakarta: PT Grasindo.
Zainal Aqib. 2002. Profesionalisme Guru dalam Pembelajaran. Jakarta : Insan Cendekia. 